\title{
Tort
}

\section{Accrual of a cause of action}

\section{by Andrew Tettenborn}

Surprisingly enough to laymen, though not of course to lawyers, our judges spend a great deal of time and effort. deciding not whether a cause of action exists, but the precise moment at which it came into being. The obvious reason for this seemingly casuistic exercise is the need to be able to apply the rules on limitation of actions, but there are others: for example, the computation of the date from which an award of interest ought to run. The latest decision of the House of Lords on this point, while apparently impeccable in terms of legal logic, promises to make the trial of certain professional negligence actions a good deal more fraught than it was before.

The case in question is Nykredit $v$ Edward Erdman \& Co [1997] 1 WLR 1627, one of a recent group of actions by mortgagees against valuers, dating from the heady days of the late 1980s when it was widely believed that land values would continue to defy the law of gravity. The facts were, so to speak, routine: Nykredit lent some $£ 2 \mathrm{~m}$ on grossly overvalued commercial property, and lost heavily when neither the security nor the lender's other assets were adequate to reimburse them. Having been up to the House of Lords once on the question of the measure of damages against the valuers in question, the case returned to it on what looked like a thoroughly subsidiary point: when should interest start to run on those damages?

\section{WHEN IS A LOSS SUFFERED?}

The answer, as a matter of principle, was easy: it must be from when the cause of action in tort arose - that is, when loss was first suffered. But when was that? The date of the advance, said the lenders, as that was when their funds were ventured on ultimately unsatisfactory security. The surveyors argued that it was the date when the security was ultimately sold at a knock-down price; it was only then that the lenders' loss was cemented - indeed, until that time it could not have been said with any certainty whether there would be a loss at all.
Their Lordships held for the lenders, rejecting the view that loss only occurred when the property was sold (or, if it was never sold, the date when it ought to have been sold). But in so doing they held that the choice was not necessarily as simple as that put forward in the parties' rival contentions. In determining when a loss was suffered, account had to be taken of all sources of repayment available to the lender: both the security and also the borrowers' personal covenant (together, no doubt, with the potential recovery from any sureties, though that did not arise in Nykredit). A person lending even against worthless security, their Lordships said, was not damnified in so far as the borrower himself remained able to repay the advance: it was only when (if ever) the borrower's ability ceased that any loss, and hence any cause of action, arose. It was only because their Lordships were satisfied that, in the event, the borrowers' covenant had been worthless from the start, that they decided that the relevant date was that of the advance.

\section{MAKING LIFE DIFFICULT}

It is suggested that, logical as this decision might look, it is a little odd: it also has the potential to make life highly awkward for legal advisers and their clients.

First there is a point of principle. The lender in a typical misvaluation case may well not expect to receive repayment of the principal sum until the end of the period of the loan, or (in the case of default) until he takes steps to realise his security (assuming it is not a mortgage requiring repayment of instalments of principal during its currency). If so, it is a little unreal to regard him as suffering loss at an earlier time: barring any loss of interest, his cash-flow is then in precisely the position he expected (and hoped) that it would be. If that is the case, the argument for the surveyors seems entirely logical: no cause of action should arise until actual or imputed realisation.

This point is borne out by a second. In respect of the period before the security was (or should have been) realised, it is not entirely clear why the lender should receive any interest under the Supreme Court Act 1981 anyway. The surveyor, after all, did not advise as to the ability of the borrower to pay interest on the capital advanced: he merely advised as to the value of the property put up as security for that sum. There is yet another point. What of the situation where, after the borrower's personal covenant has become inadequate, he nevertheless pays instalments of interest? If the lender recovers interest from the date of inadequacy, he is effectively being paid twice for the use of the same money. It is to be hoped that, notwithstanding Nykredit, the courts will be able to see their way to deducting such interest as was actually received.

Furthermore, in so far as the lender can show that, but for the surveyor's advice, he would have laid out his funds elsewhere at usury, the interest he would have received on those funds can, in any case, be claimed as damages (see, for example, East v Maurer [1991] 2 All ER 733).

\section{CASES OF LIMITATION}

However the most important problem, from a practical point of view, with Nykredit is that similar criteria to those used by their Lordships must presumably now apply to cases of limitation, and that for these purposes it is often going to be remarkably difficult to advise on whether a cause of action for misvaluation is statute-barred. Not infrequently, the personal covenant of the borrower and/or any sureties will (when combined with the value of the property) have been adequate at the time the loan is made, and will only later become insufficient. It follows that legal advisers asked to deal with an apparently simple limitation point will have to engage in lengthy investigation of the borrower's accounts and those of any sureties - doubtless requiring expert help from accountants and the like - together with a good deal of speculation as to the likely amount that would have been forthcoming at various times had proceedings been brought against them. To this will have to be added further speculation as to when the 
deficiency ought to have been discovered under the provisions of s. 14A of the Limitation Act 1980, so as to allow the limitation clock to start ticking. The extra time and costs involved are likely to be substantial, particularly because in the light of such uncertainties, disputes and litigation on limitation are likely to increase considerably. This is, to say the least, worrying.

Nor, it might be added, can much comfort be taken, in this connection, from the Law Commission's recent suggestions for reform of the law of limitation of actions (Consultation Paper on Limitation, No. 151 (1997)). For, although the commission rightly suggests that the date of accrual of a cause of action, with all its messiness and arbitrary character, should be downgraded in favour of a standard limitation period of threc years from the date of discoverability, the date of accrual will nevertheless remain very relevant. For the matters of which the plaintiff must have actual or constructive knowledge would include (as at present) not only the facts of negligence and the identity of the potential defendant, but also the fact that the damage which has been suffered is 'significant' (12.28ff.) and this throws the enquiry straight back to where it started - namely, when was loss first suffered. Plus ça change ...

(E)

\section{Professor Andrew Tettenborn}

University of Exeter

\section{Taxation}

\section{Charges to stamp duty as consideration by Janice B Shardlow}

The imposition of a charge to taxation at a fixed point in time by reference to consideration inevitably causes complications where some of that consideration is contingent and accordingly may not eventually be paid. In the case of capital gains tax, a solution is found in s. 48 of the Taxation of Chargeable Gains Act 1992, which provides for an initial charge to capital gains tax on the basis that the contingent consideration will be paid, with a rebate of tax should the sum eventually prove to be irrecoverable.

\section{on the internet} http://www.inlandrevenue.gov.uk

The Inland Revenue home page is a useful starting point for any research concerning taxation. The site provides access to press releases, copies of statements of practice and consultation documents.

In the case, however, of the somewhat 'archaic' charge to stamp duty, dependent on submission of a document to the Inland Revenue and assessment of the charge on the document at the point of submission with reference to the circumstances at the date of execution of the document ( $W m$ Cory \& Son Ltd v IRC [1965] AC 1088), the problem has been dealt with by the evolution of a principle generally known as 'the contingency principle'. In its simplest form this allows duty on an instrument:

'not only by reference to any sum which is conditionally payable but also by reference to any sum which is payable contingently or conditionally, that is to say on a sum which may become payable' (Coventry CC V IRC [1978] STC 151).

In other words to assume the contingency will occur and assess on that basis. Due to the 'one-off' nature of the tax there is no prospect of a rebate should the contingency not actually occur; on the other hand it also follows that no charge can be imposed by reference to consideration which is incapable of ascertainment at that date (IRC $v$ Littlewood Mail Order Stores Ltd [1963] AC 135).

The contingency principle has gradually been extended over the years to deal with the situation where a contingent sum would appear to be unascertainable, in the sense that its precise amount cannot be fixed at execution, but it is nevertheless subject either to a maximum or minimum. In such an event the principle has been applied to levy a charge by reference to that maximum or minimum by taking it as a 'prima facie sum' or 'basic payment' (Independent Television Authority $v$ IRC [1961] AC 427), contingently payable on the relevant contingency arising. A charge to tax has accordingly been levied, in effect on a double contingency, i.e. on the basis of two assumptions:

(1) that events will be such that a sum will be payable; and
(2) that events will be such that the sum will be equal to the stated. maximum/minimum.

The recent case of $L_{0} M$ Tenancies 1 plc $V$ Commissioners of Inland Revenue (Court of Appeal (Civil Division), 28 January 1998) would appear to have taken the principle one step further, applying a new permutation, which it was initially thought would apply only in the case of a charge on periodic payments, to a single payment on a conveyance on sale.

\section{STAMP DUTY ON LEASES}

The case centred on the application of stamp duty to the consideration to be paid on two leases granted by St John's College, Cambridge, on 14 August 1993. In each case the lease provided that the tenant should pay an annual rent and a premium, each of which was to be calculated in accordance with a formula. In the case of the rent this was to be determined with reference to the net letting income of the property for the year in question, and in the case of the premium the formula was expressed to be an amount equal to ' $a$ ' $x$ ' $b$ ', where ' $a$ ' was a specified figure and ' $b$ ' was the price of $13.75 \%$ Treasury loan stock at the close of business on the 25 th business day following the execution of the lease. It was not disputed that the formula had in each case been adopted in an attempt to avoid stamp duty.

The Revenue, in assessing the stamp duty to be charged under para. 3 of the head of charge 'lease or tack' on the leases, agreed with the appellant that no 